\title{
Hubungan Dukungan Sosial Teman Sebaya terhadap Motivasi Berprestasi pada Remaja Awal di Kota Denpasar
}

\author{
A.A Ayu Rianika Wijaya dan Putu Nugrahaeni Widiasavitri \\ Program Studi Sarjana Psikologi, Fakultas Kedokteran, Universitas Udayana \\ amandarianika@gmail.com
}

\begin{abstract}
Abstrak
Motivasi berprestasi merupakandaya penggerak yang memotivasi semangat seseorang, mendorong seseorang untuk mengembangkan kreativitas dan menggerakkan semua kemampuan serta energi yang dimilikinya demi mencapai prestasi yang maksimal.Motivasi berprestasi mulai tumbuh pada usia remaja awal dimana mulai membentuk kebiasaan untuk mencapai suatu keberhasilan.Tujuan penelitian ini yaitu untuk mengetahui hubungan terkait dukungan sosial teman sebaya terhadap motivasi berprestasi pada remaja awal di Kota Denpasar.Data Dinas Pendidikan Kota Denpasar mencatat bahwa prestasi remaja awal di Kota Denpasar tebilang tinggi. Peningkatan motivasi berprestasi salah satunya dipengaruhi oleh dukungan sosial teman sebaya, teman sebaya memiliki peran penting dalam perkembangan remaja terutama pada tahapan perkembangan belajar dimana remaja yang banyak memiliki teman akan mampu meningkatkan minat terhadap pendidikan guna meningkatkan motivasi berprestasi. Sampel penelitian ini berjumlah 92 orang dengan metode analisa data yang digunakan adalah metode korelasi Pearson Product Moment. Hasil koefisien korelasinya yang diperoleh sebesar (+) 0,477 menunjukan adanya hubungan antara variabel dukungan sosial teman sebaya terhadap motivasi berprestasi dan berada pada intensitas yang cukup kuat. Tanda positif (+) menunjukkan bahwa semakin positif dukungan sosial teman sebaya maka akan mengakibatkan semakin positif pula motivasi berprestasi.
\end{abstract}

Kata kunci: dukungan sosial, teman sebaya, remaja awal, motivasi berprestasi.

\begin{abstract}
Achievement motivation encourages someone to develop creativities and expend the abilities to achieve the best results. Achievement motivation begin to be formed in early adolescence when they began to form the habits of achieving goals. This research was aimed to see if there is a relationship between social support of peer group to achievement motivation on early adolescence in Denpasar. Denpasar education offices data shown that early adolescent achievement in Denpasar are quite good. An increase in achievement motivation one is influenced by social support of the peer group which is has an important role in learning development stage of adolescents. The number of the sample in this study amounted to 92 samples which is processed by Pearson Product Moment correlation method. The result of this research showed that social support of peer group on early adolescent significantly positive affect achievement motivation on early adolescent in Denpasar with the correlation coefficient value obtained at (+) 0.477 which is shows the existence of a significant positive relationship between variables of peer group social support for achievement motivation on early adolescent in Denpasar.
\end{abstract}

Key words: social support, early adolescent, peer group, achievement motivation. 


\section{LATAR BELAKANG}

Motivasi berprestasi merupakan bekal untuk mencapai sukses (Sepfitri, 2011). Motivasi berprestasi berkaitan dengan pemikiran yang berhubungan dengan melakukan sesuatu yang baik, lebih baik dari sebelumnya dan lebih efisien (McClelland, 1987). Daya penggerak yang memotivasi semangat seseorang, mendorong seseorang untuk mengembangkan kreativitas dan menggerakkan semua kemampuan serta energi yang dimilikinya demi mencapai prestasi yang maksimal disebut dengan motivasi berprestasi (McClelland dalam Djamarah, 2011). Motivasi berprestasi yang akan diuji dalam penelitian ini berkaitan dengan bidang akademik. Motivasi beprestasi dalam bidang akademik merupakan motivasi yang mengarah pada perilaku individu untuk mencapai prestasi yang optimal dalam kegiatan pembelajaran di sekolah (McClelland dalam Khairani, 2013).

McClelland (1987) menjelaskan ciri-ciri individu yang memiliki motivasi berprestasi tinggi meliputi bertanggungjawab dengan tugas yang dikerjakan, menerima umpan balik, memperhatikan risiko pemilihan tugas, tekun dan ulet dalam bekerja, melakukan tugas dengan penuh pertimbangan dan perhitungan, dan berusaha untuk melakukan sesuatu dengan cara yang kreatif. Hasil studi pendahuluan yang dilakukan peneliti berkaitan dengan motivasi berprestasi didapatkan hasil 11 siswa diduga menunjukkan sikap dan perilaku yang mencerminkan motivasi berprestasi, dimana hal tersebut ditunjukkan melalui sikap dan perilaku yang ingin menyelesaikan tugas tepat waktu dengan tidak menunda waktu untuk mengerjakan tugas dan siswa lebih berorientasi untuk mengerjakan tugas ataupun ujian dengan baik untuk mendapatkan nilai yang memuaskan dengan cara mengatur teknik belajar yang benar dan mengikuti beberapa kegiatan belajar tambahan diluar jam sekolah, sedangkan 4 siswa memiliki sikap dan perilaku yang mengarah pada motivasi berprestasi rendah antara lain hanya menjadikan penjelasan guru di sekolah sebagai sumber informasi dalam belajar, menunda waktu dalam mengerjakan tugas sekolah dan lebih memilih untuk bermain atau menonton televisi dibandingkan mengikuti kegiatan belajar tambahan (Wijaya, 2018). Siswa dengan motivasi berprestasi tinggi memiliki tingkat usaha yang lebih untuk mencapai suatu prestasi dibandingan dengan siswa yang memiliki motivasi berprestasi rendah. Keinginan siswa untuk sukses mendorong untuk menyelesaikan tugas tepat waktu tanpa memperdulikan tingkat kesulitan tugas tersebut (Solih, 2015).

Masa remaja adalah masa untuk berprestasi, dimana para remaja akan menyadari bahwa pada saat ini dituntut untuk menghadapi kehidupan yang sebenarnya yang sarat akan persaingan (Prabhadewi, 2014). Hurlock (1980) menjelaskan motivasi berprestasi tumbuh pada usia remaja awal dimana mulai terbentuk kebiasaan untuk mencapai suatu keberhasilan. Penelitian ini melibatkan siswa dan siswi Sekolah Menengah Pertama (SMP) di Kota Denpasar dengan katagori usia remaja awal pada rentang usia 12 tahun sampai dengan 15 tahun, hal ini sesuai dengan peraturan Kementerian Pendidikan dan Kebudayaan Republik Indonesia no. 04/VI/PB/2011 (2018) mengenai syarat untuk menjadi peserta didik pada tingkat Sekolah Menengah Pertama. Penelitian ini dilaksanakan di Kota Denpasar karena motivasi berprestasi pada siswa dan siswi SMP di Kota Denpasar terbilang tinggi, hal ini dapat dilihat berdasarkan data dinas pendidikan Kota Denpasar (2016) mencatat siswa SMPN 8 Denpasar meraih nilai Ujian Nasional tertinggi di Provinsi Bali, selain itu lima siswa SMP dari Kota Denpasar masuk dalam rangking peraih Ujian Nasional tertinggi di Provinsi Bali, selain itu siswa-siswi SMP di Kota Denpasar juga sering mendapatkan penghargaan dalam bidang akademik maupun non akademik, seperti sebanyak 11 orang siswa-siswi SMP Kota Denpasar berhasil menorehkan prestasi pada ajang Olimpiade Sains Nasional (OSN) Tingkat Nasional Tahun 2016 di Palembang, Sumatera Selatan (Bali Antara News, 2016).

Motivasi berprestasi pada remaja, salah satunya dipengaruhi oleh dukungan sosial (Sepfitri, 2011). Dukungan sosial merupakan bentuk pemberian informasi dimana seseorang merasa dirinya dicintai dan diperhatikan, terhormat dan dihargai, serta adanya hubungan timbal balik dari lingkungan sosial baik dari guru, orangtua atau teman sebaya (Taylor dalam Sepfitri, 2011). Teman sebaya memiliki peran penting dalam perkembangan remaja terutama pada tahapan perkembangan belajar dimana remaja yang banyak memiliki teman akan mampu meningkatkan minat terhadap pendidikan guna meningkatkan motivasi berprestasi, ataupun sebaliknya memilih teman yang salah yaitu menjerumuskan ke arah yang tidak baik (Sepfitri, 2011).

Pengaruh teman sebaya paling kuat adalah pada masa remaja awal yaitu usia 12-13 tahun (Saguni \& Amin, 2014). Pengaruh kuat teman sebaya merupakan hal yang penting dan tidak dapat diremehkan pada masa perkembangan remaja awal (Mappiare, 2000). Hasil wawancara pada 15 remaja awal di Kota Denpasar berkaitan dengan faktor-faktor yang dapat meningkatkan motivasi berprestasi, didapatkan 9 remaja awal menyatakan bahwa salah satu faktor dalam meningkatan motivasi beprestasi adalah teman sebaya. Teman sebaya akan menumbuhkan daya saing untuk dapat menjadi lebih baik dibandingkan dengan teman-temannya. Teman sebaya juga merupakan sumber yang digunakan remaja awal untuk saling bertukar informasi baik dalam bidang akademis yaitu pelajaran maupun pada bidang non akademis yaitu hobi (Wijaya, 2018).

Pada kenyataannya, tidak semua remaja awal mendapatkan dukungan sosial teman sebaya. Margono (2014) menjelaskan remaja yang mendapatkan penolakan atau tidak diperhatikan dari teman sebaya akan merasa kesepian dan timbul rasa permusuhan, sehingga remaja tersebut memiliki rasa harga diri yang rendah dan prestasi belajar yang kurang. Remaja yang memiliki teman sebaya akan cenderung lebih mampu untuk mengatasi transisi normatif dan peningkatan pada kualitas hidupnya seperti prestasi belajar dan daya bersaing, dibandingkan dengan anak yang tidak memiliki teman sebaya (Saguni \& Amin, 2014).

Adapun pengaruh dukungan sosial teman sebaya dapat menjadi positif maupun negatif. Ikshan (2013) mengidentifikasi salah satu faktor penghambat kegagalan akademik yaitu pengaruh negatif kenakalan teman sebaya seperti bolos sekolah, tawuran dan penggunaan obat terlarang. Remaja awal di Kota Denpasar sendiri tidak luput dari pengaruh negatif teman sebaya seperti berita Tribune Bali 
(2017) dimana terdapat 9 pelajar SMP di Kota Denpasar yang diketuai oleh remaja usia 15 tahun menjadi pelaku begal di daerah Denpasar dan Kuta. Dukungan sosial teman sebaya tidak selamanya negatif, berdasarkan hasil wawancara peneliti dengan guru SMP di Kota Denpasar menjelaskan melalui pengamatan terkait faktor yang dapat meningkatkan motivasi berprestasi siswa yaitu padangan siswa tentang mata pelajaran, teknik guru dalam mengajar dan dukungan sosial teman sebaya. Remaja awal cenderung menjadikan teman sebaya sebagai pesaing untuk mendapatkan nilai yang baik, selain itu remaja awal juga membentuk kelompok-kelompok belajar untuk dapat meningkatkan prestasi belajarnya (Wijaya, 2018).

Melihat kenyataan remaja awal di Kota Denpasar terkait dengan motivasi berprestasi dengan dukungan sosial teman sebaya, membuat peneliti ingin mengetahui apakah ada hubungan dukungan sosial teman sebaya dengan motivasi berprestasi pada remaja awal, dengan fokus pada remaja awal yang ada di Kota Denpasar, mengingat usia remaja awal merupakan usia rentan remaja akan pengaruh dari teman sebaya.

\section{METODE PENELITIAN}

\section{Variabel dan Definisi Operasional}

Variabel penelitian merupakan suatu atribut atau sifat atau nilai dari orang, objek atau kegiatan yang mempunyai variasi tertentu yang ditetapkan oleh peneliti untuk dipelajari dan kemudian ditarik kesimpulannya. Variabel merupakan objek penelitian yang menjadi perhatian suatu penelitian (Sugiyono, 2012). Pada penelitian ini variabel tergantung yaitu motivasi berprestasi pada remaja awal di Kota Denpasar dan variabel bebas adalah dukungan sosial teman sebaya.

Azwar (2013) menyatakan bahwa definisi operasional adalah suatu definisi mengenai variabel yang dirumuskan berdasarkan karakteristik-karakteristik variabel yang diamati. Definisi operasional variabel-variabel dalam penelitian ini adalah:

Motivasi Berprestasi

Motivasi berprestasi merupakan dorongan untuk berbuat sebaik mungkin, agar memperoleh hasil yang terbaik sesuai dengan kondisi yang diharapkan, dengan cara berusaha keras, dan mengungguli orang lain berdasarkan suatu standar mutu tertentu. Dengan demikian, motivasi berprestasi seseorang tidak terlepas dari pengetahuan dan keterampilan yang diperoleh dari belajar, yang dalam hal ini juga ditunjukkan oleh intensitas untuk kerja dalam suatu tugas. Taraf motivasi berprestasi diukur menggunakan skala motivasi berprestasi. Semakin tinggi skor total yang diperoleh, maka semakin tinggi taraf motivasi berprestasi subjek.

\section{Dukungan Sosial Teman Sebaya}

Dukungan sosial teman sebaya merupakan salah satu bentuk ikatan secara sosial yang menggambarkan kualitas dari hubungan interpersonal antara anak-anak atau remaja yang memiliki usia atau tingkat kematangan yang kurang lebih sama, serta merupakan sumber dukungan emosional penting sepanjang transisi masa remaja. Taraf dukungan sosial teman sebaya diukur menggunakan skala dukungan sosial teman sebaya. Semakin tinggi skor total yang diperoleh, maka semakin tinggi taraf dukungan sosial teman sebaya yang dimiliki oleh subjek.

\section{Subjek}

Populasi yang digunakan pada penelitian ini adalah remaja awal yang berusia 12 sampai dengan 15 tahun yang merupakan siswa-siswi SMP di Kota Denpasar. Berdasarkan data yang diperoleh dari arsip Dinas Pendidikan Kota Denpasar (2017), terdapat 63 SMP di Kota Denpasar terdiri atas 12 sekolah negeri dan 51 sekolah swasta. Teknik pengambilan sampel yang dilakukan dalam penelitian ini adalah dengan menggunakan salah satu probability sampling yaitu cluster sampling (area sampling). Teknik sampling daerah digunakan untuk menentukan objek yang akan diteliti atau sumber data sangat luas.

Teknik sampling daerah ini sering digunakan melalui dua tahap yaitu tahap pertama menentukan sampel daerah dan tahap berikutnya menentukan orang-orang yang ada pada daerah tersebut dengan menggunakan cluster sampling juga (Sugiyono, 2015). Proses random dilakukan untuk memperoleh sampling daerah dan sampling individu. Tahap awal penelitian ini menentukan sampel daerah dengan melakukan pengundian terhadap 63 sekolah di Kota Denpasar. Hasil random pertama pada 63 SMP di Kota Denpasar tersebut yaitu SMP Negeri 10 Denpasar. Setelah sekolah diperoleh, peneliti kemudian melakukan pengundian tahap kedua yaitu mengundi kelas yang akan dijadikan sampel pada penelitian ini. Hasil random kedua yaitu kelas VII D, VIII B, dan IX A. Menurut Azwar (2015) secara tradisional, statistika menganggap jumlah sampel yang lebih dari 60 orang sudah cukup banyak.

\section{Tempat dan Waktu Penelitian}

Penelitian dilakukan pada Bulan Maret 2018. Subjek pada penelitian ini adalah siswa-siswi yang berusia 12 sampai 15 tahun yang sedang menempuh pendidikan di SMP Negeri 10 Denpasar. Pada Hari Kamis, 1 Maret 2018 peneliti menemui kepala sekolah dan bagian kesiswaan SMP Negeri 10 Denpasar untuk memberikan surat pengantar dan menyampaikan ijin untuk melakukan penelitian. Setelah surat ijin melakukan penelitian diterima, peneliti mulai melakukan pengambilan data pada tanggal 5 Maret 2018 di SMP Negeri 10 Denpasar.

\section{Alat Ukur}

Alat ukur yang digunakan pada penelitian ini adalah skala motivasi berprestasi dan skala dukungan sosial teman sebaya. Skala motivasi berprestasi menggunakan skala motivasi berprestasi dari penelitian Prabadewi (2013) yang disusun berdasarkan komponen-komponen motivasi berprestasi menurut McClelland (dalam Djamarah, 2011). Model skala yang digunakan yaitu skala likert yang terdiri dari 32 butir aitem yang terdiri dari 16 aitem favorable dan 16 aitem unfavorable. Skala dukungan sosial teman sebaya disusun berdasarkan komponen-komponen dukungan sosial teman sebaya yang dikemukakan oleh House dalam Smet (1994). Model skala yang digunakan yaitu skala likert yang terdiri dari 36 butir aitem yang terdiri dari 18 aitem favorable dan 18 aitem unfavorable. Skala dalam penelitian ini merupakan 
skala likert yang menggunakan empat pilihan jawaban, yaitu sangat setuju (SS), setuju (S), tidak setuju (TS), dan sangat tidak setuju (STS).

Validitas konstruk tersebut menunjukkan sejauhmana suatu alat ukur mampu mengukur trait atau konstruk teoritik yang akan diukur peneliti (Azwar, 2010). Menurut Cronbach (dalam Azwar, 2015), suatu aitem dengan koefisien yang berkisar antara 0,3 sampai dengan 0,5 telah dapat memberikan kontribusi yang baik. Uji validitas dilakukan dengan metode Cronbach's Alpha pada perangkat lunak SPSS release 20.0. Validitas isi menunjukkan sejauhmana suatu aitem-aitem pada alat ukur dapat mencerminkan keseluruhan konten atau kawasan isi yang hendak diukur secara komprehensif, relevan dan tidak keluar dari batasan tujuan pengukuran. Pengukuran terhadap validitas isi dilakukan dengan teknik professional judgement yang dilakukan oleh dosen pembimbing skripsi dan penyesuaian aitem-aitem dalam alat ukur tersebut dengan cetak biru (blueprint) atau indikator perilaku yang hendak diukur (Azwar, 2015).

Pada skala motivasi berprestasi mengasilkan 32 butir aitem yang valid dengan nilai reliabilitas sebesar 0,924. Pada skala dukungan sosial teman sebaya telah dilakukan uji validitas yang terdiri dari 36 aitem. Uji validitas tersebut menghasilkan 23 aitem valid. Aitem-aitem yang valid memiliki koefisien korelasi aitem-total berkisar antara 0,307 sampai 0,622 dengan koefisien Alpha $(\alpha)$ sebesar 0,839 memiliki arti bahwa skala dukungan sosial teman sebaya mampu mencerminkan $83,9 \%$ variasi skor murni subjek.

\section{Prosedur pengambilan data}

Teknik pengambilan data yang dilakukan dengan melakukan probability sampling yaitu cluster sampling (area sampling) untuk memilih SMP yang mewakili kriteria sampel berusia 12 sampai 15 tahun yang sedang menempuh pendidikan SMP di Kota Denpasar. Hasil random pertama pada 63 SMP di Kota Denpasar tersebut yaitu SMP Negeri 10 Denpasar. Setelah sekolah diperoleh, peneliti kemudian melakukan pengundian tahap kedua yaitu mengundi kelas yang akan dijadikan sampel pada penelitian ini. Hasil random kedua yaitu kelas VII D, VIII B, dan IX A. Pada Hari Kamis, 1 Maret 2018 peneliti menemui kepala sekolah dan bagian kesiswaan SMP Negeri 10 Denpasar untuk memberikan surat pengantar dan menyampaikan ijin untuk melakukan penelitian. Setelah surat ijin melakukan penelitian diterima, peneliti mulai melakukan pengambilan data pada tanggal 5 Maret 2018 di SMP Negeri 10 Denpasar.

Skala yang disebar oleh peneliti terdiri dari inform concern, identitas diri, petunjuk pengisian, skala motivasi berprestasi dan skala dukungan sosial teman sebaya. Pada proses pengambilan data penelitian, peneliti menyebarkan kuesioner kepada seluruh siswa-siswi yang berada di kelas. Pada masing-masing kelas peneliti menyebarkan 30 sampai 31 kuesioner. Kuesioner yang disebarkan berjumlah 92 buah dan seluruhnya dapat digunakan sebagai data penelitian.

\section{Teknik Analisis Data}

Metode analisa data yang digunakan dalam penelitian ini adalah metode korelasi Pearson Product Moment untuk mengetahui hubungan motivasi berprestasi dengan dukungan sosial teman sebaya. Sebelum melakukan uji hipotesis, dilakukan uji asumsi peneitian yaitu uji normalitas dan uji linieritas.

Uji normalitas digunakan untuk mengetahui apakah distribusi data penelitian telah menyebar secara normal. Data pada penelitian ini data dapat dikatakan terdistribusi secara normal jika nilai $\mathrm{pv}>0,05$. Uji linearitas digunakan untuk mengetahui apakah data penelitian variabel motivasi berprestasi berkorelasi secara linear dengan data variabel dukungan sosial teman sebaya. Peneliti menggunakan metode ini karena metode ini efektif dengan nilai $\mathrm{p}<0.05$.

\section{HASIL PENELITIAN}

\section{Karakteristik Subjek}

Responden dalam penelitian ini adalah remaja awal yang sedang menempuh pendidikan di SMP Negeri 10 Denpasar yang berjumlah 92 orang. Hasil deskripsi subjek berdasarkan usia menunjukkan bahwa mayoritas subjek yang mengikuti penelitian ini berusia 15 tahun dengan persentase sebesar $34,78 \%$. Hasil deskripsi subjek berdasarkan jenis kelamin menunjukkan bahwa mayoritas subjek yang mengikuti penelitian ini berjenis kelamin perempuan dengan persentase $51,08 \%$.

\section{Deskripsi Data Penelitian}

Hasil deskripsi data penelitian yaitu motivasi berprestasi dan dukungan sosial teman sebaya dapat dilihat pada rangkuman tabel 9 (deskripsi statistik data penelitian. terlampir).

Hasil deskripsi statistik pada tabel 9 menunjukkan bahwa motivasi berprestasi memiliki mean teoritis sebesar 80 dan mean empiris sebesar 88,48 sehingga menghasilkan perbedaan mean empiris dan mean teoritis motivasi berprestasi sebesar 8,48 dengan nilai $t$ sebesar 9,545. Mean empiris yang diperoleh lebih besar dari mean teoritis (mean empiris > mean teoritis) menghasilkan sebuah kesimpulan bahwa subjek memiliki taraf motivasi berprestasi yang tinggi. Berdasarkan penyebaran frekuensi menghasilkan rentang skor subjek penelitian berkisar antara 70 sampai 112, sehingga 91,30\% subjek memiliki skor di atas mean teoritis. Hasil deskripsi statistik pada tabel 9 menunjukkan bahwa motivasi berprestasi memiliki mean teoritis sebesar 80 dan mean empiris sebesar 88,48 sehingga menghasilkan perbedaan mean empiris dan mean teoritis motivasi berprestasi sebesar 8,48 dengan nilai $t$ sebesar 9,545. Mean empiris yang diperoleh lebih besar dari mean teoritis (mean empiris > mean teoritis) menghasilkan sebuah kesimpulan bahwa subjek memiliki taraf motivasi berprestasi yang tinggi. Berdasarkan penyebaran frekuensi menghasilkan rentang skor subjek penelitian berkisar antara 70 sampai 112, sehingga 91,30\% subjek memiliki skor di atas mean teoritis. 


\section{Kategorisasi Data Penelitian}

Kategorisasi motivasi beprestasi dapat dilihat pada tabel 10 (kategorisasi motivasi berprestasi. terlampir). Dari hasil kategorisasi motivasi berprestasi pada tabel 10 menunjukkan bahwa tidak ada subjek yang memiliki taraf motivasi berprestasi yang sangat rendah. Subjek dengan taraf motivasi berprestasi rendah berjumlah 2 orang $(2,17 \%)$, taraf motivasi berprestasi sedang berjumlah 47 orang $(51,1 \%)$, taraf motivasi berprestasi tinggi berjumlah 38 orang $(41,3 \%)$ dan taraf motivasi berprestasi sangat tinggi berjumlah 5 orang $(5,43 \%)$. Berdasarkan uraian tersebut maka dapat disimpulkan mayoritas subjek memiliki taraf motivasi berprestasi yang sedang.

\section{Uji Asumsi}

Penelitian ini menggunakan dua uji asumsi berupa uji normalitas dan uji linearitas. Hasil uji normalitas data penelitian dapat dilihat pada lampiran 11 dan telah dirangkum dalam tabel 12 (hasil uji normalitas data penelitian. terlampir).

Berdasarkan hasil uji normalitas, tabel 12 menunjukkan bahwa data pada variabel dukungan sosial teman sebaya berdistribusi normal dengan nilai 0,083 dan signifikansi 0,129 ( $\mathrm{p}>0,05)$.

Hasil uji linearitas pada data penelitian dapat dilihat pada rangkuman tabel 13 (uji linearitas data penelitian. terlampir). Hasil uji linearitas pada tabel 13, menunjukkan bahwa terdapat hubungan yang linear antara variabel motivasi beprestasi dan variabel dukungan sosial teman sebaya dengan signifikansi linearity sebesar 0,000 ( $\mathrm{p}<0,05)$. Dengan demikian, dapat disimpulkan bahwa terdapat hubungan linear antara motivasi berprestasi dengan dukungan sosial teman sebaya.

\section{Uji Hipotesis}

Pengolahan data untuk menguji hipotesis yang mengkorelasikan antara variabel dukungan sosial teman sebaya dengan motivasi berprestasi menggunakan metode atau teknik analisis korelasi product moment dari Karl Pearson dilakukan secara komputerisasi dengan perangkat lunak SPSS release 20.0 dengan taraf signifikansi 0.05 artinya bahwa kemungkinan penolakan hipotesis yang benar adalah 5 dari 100 .

Melalui pengolahan data pada program SPSS release 20.0 tersebut diperoleh nilai koefisien korelasi (r) sebesar 0,477. Angka korelasi yang diperoleh sebesar (+) 0,477 menunjukkan adanya hubungan antara variabel dukungan sosial teman sebaya terhadap motivasi berprestasi dan berada pada intensitas yang cukup kuat. Tanda positif (+) menunjukkan bahwa semakin positif dukungan sosial teman sebaya maka akan mengakibatkan semakin tinggi pula motivasi berprestasi. Hal ini memiliki arti bahwa kedua variabel memiliki hubungan atau saling berkorelasi.

Berdasarkan tabel 14 (hasil uji korelasi product moment. terlampir) mengenai hasil uji korelasi product moment, dijelaskan bahwa korelasi variabel dukungan sosial teman sebaya dan variabel motivasi berprestasi diperoleh nilai $\mathrm{p}$ sebesar 0,000 , dimana $\mathrm{p}<0,05$ yang berarti bahwa hipotesis nol ditolak dan hipotesis alternatif diterima, yang menyatakan bahwa ada hubungan antara dukungan sosial teman sebaya dengan motivasi beprestasi pada remaja awal di Kota Denpasar.

\section{PEMBAHASAN DAN KESIMPULAN}

\section{Pembahasan}

Hipotesis pada penelitian ini yang berbunyi ada hubungan antara dukungan sosial teman sebaya dengan motivasi berprestasi pada remaja awal di Kota Denpasar, dapat diterima. Dapat diterimanya hipotesis tersebut karena dilihat dari hasil analisis statistik yang menggunakan teknik korelasi product moment dari Karl Pearson yang koefisien korelasinya (r) antara variabel dukungan sosial teman sebaya dan motivasi berprestasi adalah 0,477 dimana nilai $p$ sebesar $0,000(p<0,05)$ yang berarti bahwa variabel dukungan sosial teman sebaya dan variabel motivasi berprestasi saling berkorelasi secara positif dan signifikan. Semakin tinggi dukungan sosial teman sebaya, maka semakin tinggi motivasi berprestasi yang dimiliki oleh remaja awal di Kota Denpasar. Sebaliknya semakin rendah dukungan sosial teman sebaya maka semakin rendah motivasi beprestasi yang dimiliki remaja awal di Kota Denpasar.

Penelitian ini diperkuat dengan kajian teori dan penelitian yang relevan. McClelland (dalam Khairani, 2013) yang mengemukakan mengenai kebutuhan berprestasi (need for achievement). McClelland (dalam Djamarah, 2011) mengatakan bahwa terdapat lima aspek yang membedakan tingkat motivasi berprestasi individu yaitu: risiko pemilihan tugas, membutuhkan umpan balik, ketekunan, tanggung jawab dan inovatif .

Dalam mengingkatkan motivasi berprestasi ada beberapa faktor yang memengaruhinya salah satunya adalah dukungan sosial. Hal ini sejalan dengan penelitian Sepfitri (2011) yang berjudul "Pengaruh Dukungan Sosial Terhadap Motivasi Berprestasi Siswa SMAN 6 Jakarta", dimana hasil penelitian tersebut menyatakan bahwa terdapat pengaruh antara dukungan sosial dan motivasi berprestasi. Sarafino (2006) menjelaskan bahwa dukungan sosial dapat berasal dari orangorang yang ada disekitar individu seperti: keluarga, rekan dan teman dekat. Pada penelitian dukungan sosial teman sebaya dipilih sebagai variabel bebas penelitian.

Teman sebaya atau yang lebih dikenal dengan peer menurut Santrock (2009) adalah anak-anak atau remaja yang memiliki usia atau tingkat kematangan yang kurang lebih sama. Pertemanan berdasarkan tingkat usia dengan sendirinya akan terjadi meskipun sekolah tidak menerapkan sistem usia. Remaja dibiarkan untuk menentukan sendiri komposisi didalam masyarakat. Salah satu fungsi terpenting dari teman sebaya adalah sebagai sumber informasi mengenai dunia di luar keluarga. Solih (2014) dalam penelitiannya menyatakan bahwa teman sebaya juga merupakan komponen yang tidak dapat dipungkiri untuk prestasi seorang remaja. Teman sebaya memiliki pengaruh yang signifikan terhadap kehidupan seorang remaja. Dukungan sosial teman sebaya merupakan salah satu bentuk ikatan secara sosial yang menggambarkan 
kualitas dari hubungan interpersonal antara anak-anak atau remaja yang memiliki usia atau tingkat kematangan yang kurang lebih sama, serta merupakan sumber dukungan emosional penting sepanjang transisi masa remaja (Santrock, 2007). Gusrianti (2012) dalam penelitiannya menjelaskan bahwa semakin baik interaksi sosial siswa dalam kelompok teman sebaya maka semakin tinggi motivasi belajar siswa. Anak yang mendapat dukungan sosial yang tinggi dari teman sebaya akan merasa bahwa dirinya dicintai, diperhatikan sehingga meningkatkan harga diri anak (Amin, 2014).

Masa kritis pertumbuhan motivasi berprestasi adalah usia sekolah, dimana remaja membentuk kebiasaan untuk mencapai keberhasilan dalam berlajar (Hurlock, 1980). Pada penelitian ini peneliti menggunakan remaja awal berusia 12 sampai dengan 15 tahun sebagai subjek penelitian. Secara umum, remaja dibagi menjadi 3 kategori usia, yaitu remaja awal (12-15 tahun), remaja madya (15-18 tahun) dan remaja akhir (18-21 tahun). Penelitian ini melibatkan 92 orang subjek penelitian yang terdiri dari remaja laki-laki dan remaja perempuan. Remaja laki-laki dalam penelitian ini adalah sebanyak 45 orang atau dalam persentase $48,92 \%$, sedangkan perempuan dalam penelitian ini sebanyak 47 orang atau dalam persentase $51,08 \%$, yang mejelaskan bahwa subjek dalam penelitian ini didominasi oleh remaja perempuan. Kriteria usia subjek dalam penelitian ini adalah pada rentang usia 12 sampai 15 tahun, dimana jumlah subjek terbanyak berada pada usia 15 tahun dan dalam persentase yaitu 34,78\%. Menurut Agustiani (2009) remaja awal berlangsung pada usia 12 sampai 15 tahun. Individu sudah mulai meninggalkan peran sebagai anak-anak dan berusaha mengembangkan diri sebagai individu yang unik dan tidak tergantung pada orang lain. Fokus dari tahap remaja awal adalah penerimaan terhadap bentuk dan kondisi fisik serta adanya konformitas yang kuat dengan teman sebaya.

Pernyataan tersebut sejalan dengan penelitian yang dilakukan oleh Amin (2014) yang mengatakan bahwa pengaruh teman sebaya paling kuat adalah pada masa remaja awal yaitu usia 12-13 tahun. Selain itu, Iksan (2013) juga mengatakan bahwa subjek usia SMP maupun SMA lebih intensif berinteraksi dengan teman daripada guru. Teman sebaya memiliki peran yang sangat penting di dalam memberikan dukungan secara langsung yakni adanya interaksi untuk membangun high level of achievement motivation seperti belajar bersama ketika akan menghadapi ujian.

Pada deskripsi data penelitian tampak bahwa pada variabel dukungan sosial teman sebaya memiliki rata-rata teoritis 57,5 dan rata-rata empiris 68,15. Hal ini menunjukkan bahwa ratarata subjek dalam penelitian ini memiliki dukungan sosial teman sebaya yang tinggi (rata-rata teoritis < rata-rata empiris). Demikian juga untuk variabel motivasi berprestasi, dimana diperoleh rata-rata teoritisnya 80 dan rata-rata empirisnya 88,48 sehingga dapat disimpulkan bahwa rata-rata subjek dalam penelitian ini memiliki motivasi berprestasi yang tinggi (rata-rata teoritis < rata-rata empiris). Melalui uraian hasil deskripsi data penelitian, tampak bahwa subjek dalam penelitian ini memiliki dukungan sosial teman sebaya yang tinggi dan motivasi berprestasi yang tinggi.
Berdasarkan kategorisasi skor yang diperoleh subjek pada skala dukungan sosial teman sebaya diketahui terdapat 23 orang atau $25 \%$ orang subjek yang memiliki dukungan sosial teman sebaya yang sangat tinggi, 43 orang atau $46,7 \%$ orang subjek memiliki dukungan sosial teman sebaya yang tinggi, 23 orang atau $25 \%$ orang subjek yang memiliki dukungan sosial teman sebaya yang sedang, 2 orang atau $2,2 \%$ orang subjek yang memiliki dukungan sosial teman sebaya yang rendah dan 1 orang atau $1,1 \%$ orang subjek yang memiliki dukungan sosial teman sebaya yang sangat rendah. Hal ini menunjukkan bahwa mayoritas remaja awal di Kota Denpasar memiliki dukungan sosial teman sebaya yang tinggi. Pada kategorisasi motivasi berprestasi 5 orang subjek atau 5,43\% yang termasuk dalam kategori sangat tinggi, kategori tinggi ada 38 orang atau $41,3 \%$ orang subjek, kategori sedang 47 orang atau $51,1 \%$ orang subjek dan 2 orang atau $2,17 \%$ orang subjek yang memiliki motivasi berprestasi rendah. Sedangkan pada kategori motivasi berprestasi sangat rendah tidak terdapat subjek atau $0 \%$. Hal ini menunjukkan bahwa mayoritas remaja awal di Kota Denpasar memiliki motivasi berprestasi yang sedang yaitu $51,1 \%$.

Hasil diatas mendukung hasil dari uji hipotesis penelitian ini yang mengatakan bahwa bila terjadi peningkatan variabel dukungan sosial teman sebaya makan akan terjadi peningkatan juga pada variabel motivasi beprestasi. Hal ini di perkuat juga dengan hasil penelitian oleh Addin (2017) yang berjudul "Hubungan antara Regulasi Diri dan Dukungan Sosial Teman Sebaya dengan Motivasi Berprestasi Siswa Kelas XI SMK Analisis Kesehatan Nasional Surakarta" yang menyatakan bahwa terdapat hubungan yang positif dan signifikan antara regulasi diri dan dukungan sosial teman sebaya dengan motivasi berprestasi. Hasil penelitian oleh Solih (2014) menjelaskan bahwa terdapat pengaruh yang cukup antara dukungan sosial teman sebaya (bantuan nyata, dukungan informasi, dukungan emosional, dan dukungan penghargaan) dengan motivasi berprestasi. Penelitian lain oleh Ulfa, dkk (2014) menjelaskan hasil bahwa terdapat pengaruh interaksi yang signifikan antara model pembelajaran kooperatif teknik tutor sebaya dan motivasi berprestasi siswa terhadap hasil belajar TIK. Sundari (2010) menjelaskan bahwa remaja yang mendapat dukungan emosional dari teman sebaya akan merasa dirinya dicintai, diperhatikan sehingga meningkatkan rasa harga diri. Seseorang dengan harga diri yang tinggi cenderung memiliki rasa kepercayaan diri yang tinggi, keyakinan diri bahwa remaja awal mampu menguasai situasi dan memberikan hasil yang positif baik dalam mengatasi permasalahan ataupun mencapai sebuah prestasi.

Penelitian lain yang dapat memperkuat hasil uji hipotesis adalah penelitian oleh Iman (2014) yang mengemukakan bahwa terdapat pengaruh positif dan signifikan interaksi teman sebaya terhadap motivasi belajar. Ahady (2010) dalam penelitiannya menghasilkan hasil yang postif berdasarkan uji korelasi yang dilakukan, artinya semakin tinggi dukungan sosial teman sebaya yang diberikan pada siswa maka semakin tinggi pula motivasi belajar siswa kelas VII SMP Islam Almaarif 01 Singosari. 
Berdasarkan hasil wawancara pada remaja awal di Kota Denpasar mengenai faktor yang memengaruhi motivasi berprestasi ditemukan bahwa 4 dari 15 siswa mengatakan bahwa guru dan harapan orangtua adalah faktor untuk berprestasi. Hal ini sejalan dengan penelitian Solih (2014) yang berpendapat bahwa guru dan teman sebaya mempunyai pengaruh yang penting dalam diri anak-anak atau remaja semasa pendidikan sekolah. Guru menjadi simbol otoritas yang menciptakan ruang kelas, bentuk interaksi sosial, serta karakter dari fungsi kelompok. McClelland (dalam Khairani, 2013) juga menjelaskan bahwa orangtua yang mengharapkan anaknya bekerja keras dan berjuang untuk mencapai sukses akan mendorong anak tersebut untuk bertingkah laku yang mengarah kepada pencapaian prestasi. Pada penilaian diperoleh bahwa orangtua dari anak yang berprestasi melakukan beberapa usaha khusus terhadap anaknya. Selain itu, hasil penelitian dari Puspitasari (2010) mengemukakan bahwa sesama siswa dapat menjadi tutor yang efektif. Dalam tutoring teman sebaya, seorang siswa mengajar siswa lainnya. Berdasarkan penelitian diatas telah ditemukan bahwa tutoring teman sebaya sering kali membantu prestasi siswa.

Setelah melalui prosedur penelitian dan analisa data yang sesuai, penelitian ini telah mencapai tujuannya yaitu mampu mengetahui bahwa dukungan sosial teman sebaya mempunyai hubungan yang positif dengan motivasi berprestasi pada remaja awal di Kota Denpasar serta berhasil membuktikan hipotesis yang berbunyi bahwa ada hubungan antara dukungan sosial teman sebaya dengan motivasi berprestasi pada remaja awal di Kota Denpasar.

\section{Keterbatasan Penelitian}

Keterbatasan pada penelitian ini yaitu masih ada beberapa subjek yang kurang serius memberikan jawaban pada kuesioner, hal ini dapat diantisipasi peneliti dengan memberikan skala pada masing-masing subjek dan peneliti langsung mendampingi subjek dalam mengisi skala, serta kesulitan dalam menentukan waktu pengambilan data karena subjek merupakan siswa dimana peneliti harus menyesuaikan jadwal dengan kalender pendidikan.

\section{DAFTAR PUSTAKA}

Agustiani, H. (2009). Psikologi Perkembangan. Jakarta: Aditama

Addin, R.A. (2017). Hubungan antara Regulasi Diri dan Dukungan Sosial Teman Sebaya dengan Motivasi Berprestasi Siswa Kelas XI SMK Analisis Kesehatan Nasional Surakarta. Surakarta: Universitas Sebelas Maret.

Ahady, N, R. (2010). Hubungan antara Dukungan Sosial Teman Sebaya dengan Motivasi Belajar pada Siswa Kelas VII di SMP Islam Almaarif 01 Singosari yang Berdomisili di Pondok Pesantren. Malang: Universitas Islam Negeri Maulana Malik Ibrahim.

Azwar, S. (2010). Dasar-Dasar Psikometri, Yogjyakarta: Pustaka Pelajar.

Azwar, S. (2014). Dasar-Dasar Psikometri, Yogjyakarta: Pustaka Pelajar.

Azwar, S.(2015). Tes Prestasi: Fungsi dan Pengembangan Pengukuran Prestasi Belajar, Edisi II, Yogjyakarta: Pustaka Pelajar.

Azwar, S. (2015). Penyusunan Skala Psikologi, Edisi 2, Yogyakarta: Pustaka Pelajar.
Azwar, S. (2014). Reliabilitas dan Validitas, Edisi 4, Yogyakarta: Pustaka Pelajar.

Bali Antara News. (2016). 11 Siswa Denpasar Raih Medali Ajang OSN. Diunduh dari: https://bali.antaranews.com/berita/91185/11-siswadenpasar-raih-medali-ajang-osn. Pada tanggal 16 September 2018.

Baron, R. A. \& Byrne, D. (1997). Social psychology: 8th edition. Massachusetts: Allyn \& Bacon.

Dinas Pendidikan Kepemudaan dan Olahraga Kota Denpasar. (2016). Siswa SMP di Denpasar Dominasi Nilai UN Tertinggi. Diunduh dari: https://pendidikan.denpasarkota.go.id/index.php/bacaberita/12456/Siswa-Denpasar-Dominasi-NUN-TertinggiSeminBali pada tanggal 12 Sepetember 2016

Dinas Pendidikan Kepemudaan dan Olahraga Kota Denpasar. (2017). Alamat SMP Negeri dan Swasta di Kota Denpasar. Diunduh https://pendidikan.denpasarkota.go.id/index.php/lihatsaran/658/alamat-SD-dan-SMP-swasta-dan-negeri-didenpasar pada tanggal 15 Mei 2017

Djamarah, Syaiful Bahri. (2011). Psikologi Belajar. Jakarta: Rineka Cipta.

Feist, J,. \& Feist, G. (2009). Teori Kepribadian Edisi 7, Buku 1. Jakarta: Salemba Humanika.

Gusrianti, Y. (2012). Hubungan Interaksi Sosial dalam Kelompok Teman Sebaya dan Motivasi Belajar Siswa Kelas IX Sekolah Menengah Pertama Negeri 1 Air Tiris Kabupaten Kampar. Pekanbaru: Universitas Islam Negeri Sultan Syarif Kasim Riau.

Hamzah, B. (2015). Teori Motivasi \& Pengukuran Analisis di Bidang Pendidikan, Jakarta: Bumi Aksara.

Hobfoll, S. E. (1986). Stress, Social Support and Women : The Series In Clinical and Community Psychology. New York : Herper dan Row.

Hurlock, E. B. (1980). Psikologi Perkembangan: Suatu Pendekatan Sepanjang Rentang Kehidupan, Edisi 5. Jakarta: Erlangga.

Iksan, M. (2013). Dukungan Sosial Pada Prestasi Dan Faktor Penyebab Kegagalan Siswa SMP dan SMA. Malang: Universitas Islam Negeri

Khairani, M. (2013). Psikologi Belajar, Yogjyakarta: Aswaja Pressindo.

King, A. L. (2014). Psikologi Umum: Sebuah Pandangan Apresiatif Edisi 1. Jakarta: Salemba Humanika.

Mappiare, A. (2000). Psikologi remaja. Surabaya: Usaha Nasional.

McClelland, D. (1987). Human Motivation. New York: Cambridge University

Menteri Pendidikan dan Kebudayaan Republik Indonesia. (2012). Peraturan Menteri Pendidikan dan Kebudayaan Republik Indonesia. Diunduh dari: http://jdih.kemdikbud.go.id/asbodoku/media/peruu/permen _tahun2012_nomor44.pdf pada tanggal 12 September 2016

Prabadewi,. \& Widiasavitri, N. (2013). Hubungan Konsep Diri Akademik dengan Motivasi Berprestasi pada Remaja Awal yang Tinggal di Panti Asuhan di Denpasar. Bali: Universitas Udayana

Prayascitta, P. (2010). Hubungan Antara Coping Stress Dan Dukungan Sosial Dengan

Motivasi Belajar Remaja Yang Orangtuanya Bercerai. Surakarta : Program

Studi Psikologi Fakultas Kedokteran Universita Sebelas Maret.

Rachmiati, T. (2010). Penggunaan Model Pembelajaran Tutor Sebaya Dalam Kelompok Kecil Untuk Meningkatkan Kualitas Pembelajaran Akuntansi Siswa Kelas XI SMA Negeri 3 Surakarta. Surakarta : Universitas Sebelas Maret Fakultas Keguruan dan Ilmu Pendidikan. 
Safaria, T. (2007). Kecenderungan Penyalahgunaan Napza Ditinjau dari Tingkat Religiusitas Regulasi Emosi, Motif Berprestasi, Harga Diri, Keharmonisan Keluarga dan Pengaruh Negatif Teman Sebaya. Universitas Ahmad Dahlan Fakultas Psikologi.

Saguni, F., \& Amin, S. (2014). Hubungan Penyesuaian Diri, Dukungan Sosial Teman Sebaya dan Self Regulation Terhadap Motivasi Belajar Siswa Kelas Akselerasi SMP Negeri 1 Palu. Palu : ISTIQRA. Seventh Edition, Jakarta.

Santoso, S. (2003). SPSS Statistik Multivariat. Jakarta: PT. Elex Media Komputindo

Santrock, J.W. (2007). Remaja Edisi 11 Jilid 1. Jakarta: Erlangga.

Santrock, J.W. (2007). Remaja Edisi 11 Jilid 2. Jakarta: Erlangga.

Santrock, J.W. (2009). Perkembangan Anak. Edisi 11. Jakarta. Erlangga

Sarafino, E. P.,\& Smith, T.W. (2006). Health Psychology : Biopsychosocial Interactions

Sarafino, E. P.,\& Smith, T.W. (2011). Health Psychology : Biopsychosocial Interactions

Sarwono, S.W., (2012). Psikologi Remaja. Jakarta: PT. Raja Grafindo Persada.

Sepfitri, N. (2011). Pengaruh Dukungan Sosial Terhadap Motivasi Berprestasi Siswa

SMAN 6 Jakarta. Jakarta : Universitas Islam Negeri Syarif Hidayatullah Fakultas Psikologi.

Slavin, E. R. (2011). Psikologi Pendidikan Teori dan Praktik Edisi 1. Jakarta : PT. Indeks.

Slavin, E.R. (2011). Psikologi Pendidikan Teori dan Praktik Edisi 2. Jakarta : PT. Indeks.

Smet, B. (1994). Psikologi Kesehatan. Jakarta: PT. Gramedia Widiasarana Indonesia

Solih, M. (2014). Pengaruh Dukungan Sosial Teman Sebaya terhadap Motivasi Berprestasi pada Siswa SMKN II Malang. Malang: Universitas Islam Negeri Maulana Malik Ibrahim.

Sugiyono. (2011). Metode Penelitian Kuantitatif Kualitatif dan R\&B. Bandung: Alfabeta

Sugiyono. (2012). Memahami Penelitian Kuantitatif Kualitatif. Bandung: Alfabeta

Sugiyono. (2014). Metode Penelitian Kuantitatif Kualitatif dan R\&B. Bandung: Alfabeta

Sugiyono. (2015). Metode Penelitian Pendidikan (Pendekatan Kuantitatif, Kualitatif dan R\&D). Bandung: Alfabeta.

Suryabrata. S. (2000). Metode Penelitian. PT. Raja Grafindo Persada, Jakarta.

Taylor, S.E. Peplau, L.A., \& Sears, D.O. (2009). Psikologi Sosial. Edisi Keduabelas. Alih Bahasa: Tri Wibowo, B.S. Jakarta: Kencana Prenada Media Group.

Tribune Bali. (2017). Meresahkan 9 Pelajar Lakukan Pembegalan di Denpasar dan Kuta, Dipimpin Bocah 15 Tahun. Diunduh dari: http://bali.tribunnews.com/2017/10/03/meresahkan-9pelajar-lakukan-pembegalan-di-denpasar-dan-kutadipimpin-bocah-15-tahun . Pada tanggal: 16 Juli 2018.

Ulfa, M., Lasmawa, W., \& Candidasa, M. (2014). Pengaruh Penerapan Model Pembelajaran Kooperatif Teknik Tutor Sebaya terhadap Hasil Belajar TIK Ditinjau dari Motivasi Berprestasi pada Siswa Kelas VII Muhammadyah Denpasar. Denpasar: Universitas Pendidikan Ganesha.

Papalia, Olds, \& Feldman. (2001). Perkembangan Manusia. Jakarta: Salemba Humanika.

Papalia, Olds, \& Feldman. (2007). Human Development (9th Edition). New York : Mc Graw Hill.

Papalia, Olds, \& Feldman, \& R. D. (2008). Human Development (terjemahan A. K. Anwar). Jakarta: Prenada Media Group.

Priyatno, D. (2012). Cara Kilat Belajar Analisis Data dengan SPSS 20. Yogyakarta: ANDI
Puspita, B. (2010). Meningkatkan Displin Belajar Siswa Melalui Manajemen Kelas. Bandung: Universitas Pendidikan Indonesia.

Wijaya, R. (2018). Hasil Wawacara Hubungan Dukungan Sosial Teman Sebaya Terhadap Motivasi Berprestasi Pada Remaja Awal Di Kota Denpasar. 


\section{LAMPIRAN}

Tabel 9

Deskripsi Statistik Data Penelitian

\begin{tabular}{|c|c|c|c|c|c|c|c|c|}
\hline Variabel & $\mathrm{N}$ & $\begin{array}{l}\text { Mean } \\
\text { Teoritis }\end{array}$ & $\begin{array}{l}\text { Mean } \\
\text { Empinis }\end{array}$ & $\begin{array}{l}\text { Std } \\
\text { Deviasi } \\
\text { Teoritis }\end{array}$ & $\begin{array}{l}\text { Std } \\
\text { Deviasi } \\
\text { Empinis }\end{array}$ & $\begin{array}{l}\text { Sebaran } \\
\text { Teoritis }\end{array}$ & $\begin{array}{l}\text { Sebaran } \\
\text { Empiris }\end{array}$ & $\mathrm{t}$ \\
\hline MB & 92 & 80 & 88,48 & 16 & 8,520 & $32-128$ & $70-112$ & 9,545 \\
\hline DS & 92 & 57,5 & 68,15 & 11,5 & 8,789 & $23-92$ & $33-83$ & 11,625 \\
\hline
\end{tabular}

Tabel 10

Kategorisasi Motivasi Berprestasi

\begin{tabular}{cccc}
\hline Rentang Nilai & Kategori & Jumlah & Presentase \\
\hline $\mathrm{X} \leq 56$ & Sangat Rendah & 0 & $0 \%$ \\
$56<\mathrm{X} \leq 72$ & Rendah & 2 & $2,17 \%$ \\
$72<\mathrm{X} \leq 88$ & Sedang & 47 & $51,1 \%$ \\
$88<\mathrm{X} \leq 104$ & Tinggi & 38 & $41,3 \%$ \\
$\mathrm{X}>104$ & Sangat Tinggi & 5 & $5,43 \%$ \\
\hline
\end{tabular}

Tabel 12

Hasil Uji Normalitas Data Penelitian

\begin{tabular}{lcc}
\hline \multicolumn{1}{c}{ Variabel } & Kolmogorov-Smimov & $\begin{array}{c}\text { Asymp.Sig (2-tailed) } \\
(\mathrm{P})\end{array}$ \\
\hline $\begin{array}{l}\text { Motivasi Berprestasi } \\
\text { Dukungan Sosial Teman }\end{array}$ & 0,092 & 0,052 \\
Sebaya & 0,084 & 0,129 \\
\hline
\end{tabular}

Tabel 13

Uji Linearitas Data Penelitian

\begin{tabular}{ccccc}
\hline & & & F & Sig. \\
\hline $\begin{array}{c}\text { Motivasi } \\
\text { Berprestasi*Dukungan } \\
\text { Sosial Teman Sebaya }\end{array}$ & $\begin{array}{c}\text { Between } \\
\text { Groups }\end{array}$ & $\begin{array}{c}\text { Linearity } \\
\text { Deviation } \\
\text { from } \\
\text { Linearity }\end{array}$ & 34,291 & 0,000 \\
& & 1,914 & 0,017 \\
\hline
\end{tabular}

Tabel 14

Hasil Uji Korelasi Product Moment

\begin{tabular}{cccc}
\hline & & $\begin{array}{c}\text { Motivasi } \\
\text { Berprestasi }\end{array}$ & $\begin{array}{c}\text { Dukungan Sosial Teman } \\
\text { Sebaya }\end{array}$ \\
\hline Motivasi & Pearson Correlation & 1 & 0,477 \\
Berprestasi & Sig. (2-tailed) & & 0,000 \\
& $\mathrm{~N}$ & 92 & 92 \\
\hline Dukungan & Pearson Correlation & 0,477 & 1 \\
Sosial Teman & Sig. (2-tailed) & 0,000 & 92 \\
Sebaya & $\mathrm{N}$ & 92 & \\
\hline
\end{tabular}

